\title{
Differences in the Value Orientation of Czech and Slovak Pupils
}

\section{Helena Vomáčková*}

\begin{abstract}
This contribution brings a selection from the results of a research carried out during the years 2013 and 2014 among Czech and Slovak pupils of middle school age (i.e. $4^{\text {th }}$ to $6^{\text {th }}$ forms of primary schools). This study focused on monitoring and evaluating the differences and similarities in the value-oriented responses of pupils, according to the criteria of their nationality and sex. The pupils were expressing their opinions by means of a questionnaire survey with respect to selected situations on a four-degree scale and they further stated their vision of the world and their position in it. This contribution analyses statistically significant deviations which were found out among the positions held by Czech and Slovak boys and girls. The contribution also gives rise to a number of questions concerning the shift in values among the population of pupils of the formerly unified state.
\end{abstract}

Key words: Czech and Slovak pupils, middle school age, value orientation, nationality.

\section{Introduction}

The split of the Czech and Slovak states in 2003 also resulted in the subsequent separation of the educational environment, which is now, more than two decades later, influenced by slightly different conditions - political, economic, legislative, social, moral, cultural, etc. Within their respective framework, both societies have been developing originality and individuality in terms of the concept of values. In both cases, there has been a shift both in values and in the value measuring scale, which, for instance on the Czech side, cannot be regarded as necessarily positive (Bělohradský, 2014, p. 7; Prudký, 2009, p. 294). Our adult population has taken them into account in a pragmatic and rational way and within the private sphere of their families who instil them into the vision of their school-age children. A wider social environment enters the process of influencing school children (Blížkovský, 1997, p. 59) by means of both the family environments (e.g. the existence of asymmetrical economic relations, such as rich vs. poor), or by means of both - peer groups (i.e. by means of the

\footnotetext{
* Helena Vomáčková, Jan Evangelista Purkyně University in Ústí nad Labem, Ústí nad Labem, Czech Republic; helena.vomackova@ujep.cz
} 


\section{Acta Technologica Dubnicae \\ volume 5, 2015, issue 2}

interaction of mutual preferences and interests), and school communities (for instance by interaction of the pro-inclusive school versus the so called elite school) and some other phenomena emanating from the social environment, for instance media (Č́a \& Mareš, 2007, p. 231). The force of the impact of these formative influences always unfolds according to the age and the level of maturity of a school child and from the immediate positive or negative effect of the social environment in which the pupil is living.

Within the research probe, attention was paid to pupils of middle-school age (Matějček, 2008, p. 57), i.e. to pupils of fourth, fifth and sixth forms from primary schools. The aim of this contribution is to submit and comment on some particular differences in the statements of Czech and Slovak pupils at that age and open room for polemics concerning the alteration in the perception of values in both communities of the formerly unified state. In spite of the limited nature of this research (partly because of its scope), its being a one-time event and in terms of values among a problematic age group (middle-school age) of the pupils - the paper draws the readers' attention to problems resulting from the underestimation of the influence of morality and character and the overestimation of such matters as moral issues or the level of intellect - which arises not only in schools but also in families and among the entire Czech society (Kohoutek, 2009, p. 1).

The author of the contribution is well aware of the controversial nature of the middle school age from the point of view of pupils' value orientation, which has just started to be formed in them. Gradually, they make it more precise and anchor it. Nevertheless, for this age, the so called "the pupil's balanced stabilization" (Matějček \& Dytrych, 2002, p. 33) is already characteristic. Within this framework, individual standards are being formed and relationships between pupils and parents become more established. Some authors call this period the age of austere realism since every pupil wants to learn gradually the answers to basic existential questions (what is it and how is it?) as opposed to younger schoolmates who are still dependent for their perception and action, on their own wishes and fantasy. For adolescents, it is more important to know what should be "correct" (Langmeier \& Krejčířová, 2006, p. 118), i.e. they start to acquire value patterns. The process of value formation predominantly concerns exteriorization, or more precisely, which of the values an individual adopts during the course of their social learning. The process of value formation is described, for instance, by Göbelová (2004, p. 22 et seq.), who, with reference to the process of internalization, calls attention not only to the significance of the family, culture and traditions, school education, financial security, intelligence, sex, belonging to a social stratum, but also to the importance of new impulses for the subsequent generation of values. She argues that among children it is in particular the pupils' personal experience that participates in the process leading to value formation. Pupils' personal experience is gradually materialized into rules and subsequently influences the auto cultivation of their values. 


\section{Acta Technologica Dubnicae \\ volume 5, 2015, issue 2}

The monitored school period is also a period in which school children start to identify themselves with their life roles according to sexes. Boys change psychologically and become "young men" and girls change into "young women". In a similar vein, Čačka $(1994$, p. 55) refers to 9-year old and 10-year old pupils who become, for a short period of time, precisely what their parents wish them to be: reliable and sensible. In return, they start to require a higher level of autonomy. They start to realise that it matters when other people decide instead of them. They want to demonstrate they are capable of following their own obligations. In spite of all these signs of progress, a pupil at that age is still a child and it is not possible to expect precocious behaviour (Langmeier \& Krejčírová, 2006, p. 119). The predominant way of thinking is still the process of thinking in concrete logical operations, when, however, a qualitative metamorphosis of their reasoning is occurring. They respect the laws of logic they can classify, discriminate, place something in a line, but they bind themselves to descriptive cognition, illustrative learning about things, to concrete objects and processes that can be perceived directly and that can be imagined, or to objects they can handle (Č́p, 2007, pp. 230-231). The characteristic features for this phase include also their ability to decentralize, preserve and be capable of reversibility (Vágnerová, 2005, p. 243). Pupils at that age start to perceive reality according to diverse points of view and take into account various relations and relationships. They are aware of the permanence of certain objects, their signs or qualities of sets, and start to realize that the reality can possess several aspects. At the same time, pupils start to understand that every action, situation is not invariable and irreversible. With logical thinking entering pupils' lives and with the extension of their time perspective, every school boy and school girl is capable of understanding at general level, certain things and phenomena as permanent value targets of their own (Langmeier \& Krejčíková, 2006, p. 132).

The value orientation of pupils of middle school age, which is characterized by attitudes to certain values, is significantly determined by the family community in which pupils are growing up. Their attitudes unfold from their own personal experience influenced by the majority's reaction to their opinions, approaches, and their actions in their immediate social environs (Bedrnová \& Nový, 2009, p. 244). This personal experience involves even attachments and emotions, models and ideals, examples and their imitation, goals, beliefs, etc. It includes a whole set of relations to the surrounding world as well as to themselves, which depends on the scope of their perception of the given reality (Horák, 1996, p. 15). In this category of pupils, it is therefore necessary to expect a tendency towards values and standards typical of their family background; whereby their personal attitudes are being shaped only gradually. Their personal experience is complemented quite significantly even by mediated experience, a source of which can emanate from a more distant social environs. It is an open process of the value formation of individuals in which their confidence is shaped along 


\section{Acta Technologica Dubnicae \\ volume 5, 2015, issue 2}

with their conviction that certain situations or ideas represent something good and desirable (Cakirpaloglu, 2009, p. 285). Values are often characterized as something that is positively assessed or that to which pupils have a positive attitude, or what they are interested in and something that represents a particular value for them. This understanding of certain values, however, has an individual character and its positive perception by an individual can be, on the contrary, accepted negatively by the wider environs. In the process of maturation, the influence of the child's group comes to the fore with the influence of specific values and unwritten standards, which sometimes come into conflict with the family values and standards. In this case, pupils find themselves in confrontation and they have to solve the problem on their own, which can be considered as a test of their value maturation.

\section{The design of the research survey and its results}

The expected partial results of this research survey complement the original study from Vomáčková and Cihláŕ (2013), which was investigating the influence of the family on the scholastic success and value orientation of the middle-school-age pupils within the Czech school environment. The additional results (2013 - 2014) acquired from the Slovak educational environment extended and improved the assessment of pupils' manifestations of values and enabled their comparison according to a new arbitrary variable: the pupils' nationality. The differences acquired in this way between Czech and Slovak pupils are examined and commented on, within this limited selection, by this contribution. It focuses on the selection of statistically significant relations which were checked by means of the Pearson chi-square test of independence at the $5 \%$ level of significance according to two criteria, sex and nationality.

The research sample was carried out among respondents from 6 districts of the Czech Republic (all of them from the Ústí Region) and 5 districts of Slovakia (from the Prešov, Trnava and the Nitra Regions). The sample included 731 school children from the fourth, fifth and sixth forms of primary schools, i.e. from 9-year old to 12-year old pupils. The tested set of respondents demonstrated a well-balanced representation (according to the Pearson chisquare test: $\mathrm{p}=0.946367)$, where from the total number of 480 Czech pupils $53.1 \%$ were boys and $46.9 \%$ girls; and from the total number of 251 Slovak pupils, $53.4 \%$ were boys and $46.6 \%$ were girls. Also the age (see fig. 1) and the gender distribution (see fig. 2) can be considered quite well-balanced. 


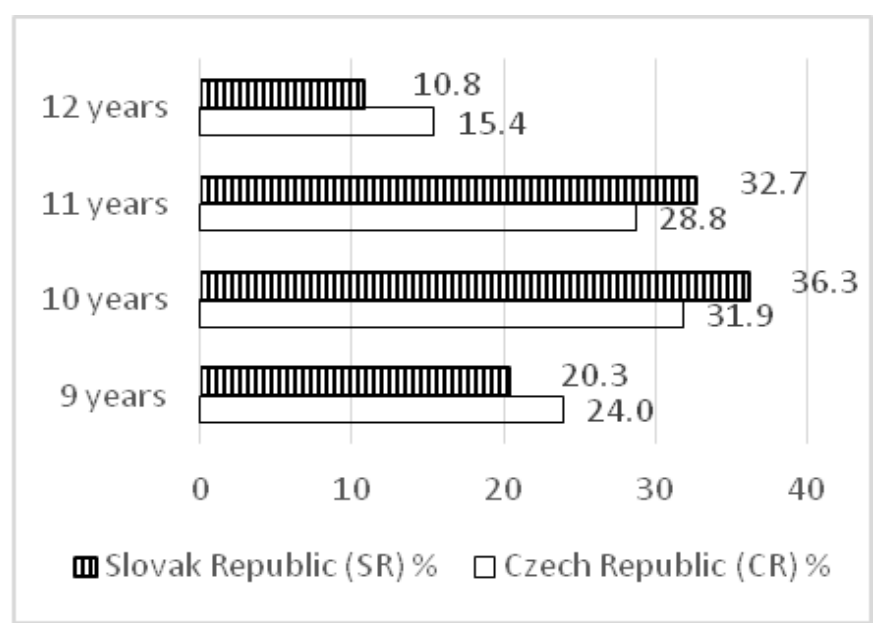

Figure 1. Distribution of respondents according to their nationality and age (\%)

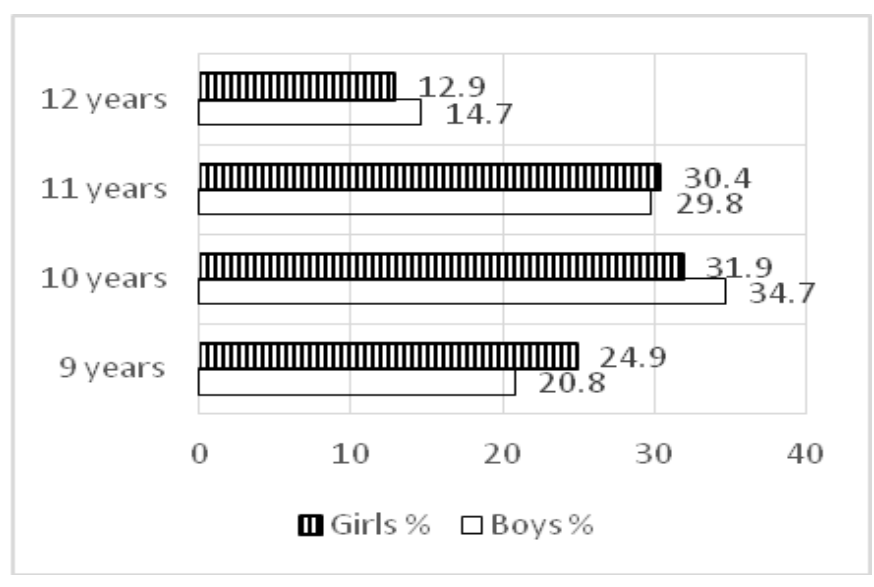

Figure 2. Distribution of respondents according to their sex and age (\%)

All respondents were answering the same questions by means of an anonymous paper questionnaire in two languages (Czech and Slovak). The questionnaire consisted of 34 items; with the first eight of them being based on facts. The other 26 questions were finding out, by means of a four-degree scale (Definitely YES, Rather YES, Definitely NOT, Rather NOT) to what extent a pupil identified with the given statements, what preferences they selected or where they placed themselves - or their family - from the point of view of their value manifestation. Along with individually evaluated manifestations of oneself, the 


\section{Acta Technologica Dubnicae}

volume 5, 2015, issue 2

research team had a chance of acquiring partial facts concerning the value preferences of these pupils, which are perceived as circumstances forming pupils in terms of the value-oriented view of the world.

With the aim of intensifying the authenticity of the questionnaire, the majority of questionnaire items were conceived as situational with attention to everyday pupils and with emphasis on their personal identity with regard to these questions (Göbelová, 2004, p. 27). In so doing, we were able to reflect on the values emanating from activities and behaviour (Horák, 1996, p. 14) and they arose as facts of consciousness by means of which they retroact and influence their activities. However, this procedure could not prevent that some of these answers would not be either overvalued or undervalued. For that reason the method of stability in time (test and retest) was applied to the estimate of specific items of the questionnaire. This method, by being repeated, checks the stability of the value of the given variable making use of an instrument that guarantees that the achieved results are also adequately stable and invariable (Ferjenčík, 2000. pp. 196-211). Its reliability was then tested in the space of four weeks with the following results: $0.812-0.868$. These values, according to Měkota and Blahuš $(1988$, p. 134) can be considered as sufficient.

The aim of this research was to find the answer to the question as to whether Czech and Slovak pupils of the same age evaluate selected situations as valueoriented or whether statistically significant differences exist between their propositions. These differences were shown in ten cases involving boys and in fifteen cases girls from 26 questions in the questionnaire. And at the same time - among both girls and boys - differences were noticed in 6 propositions. In the other cases the differences in school girl and school boy populations were concerned with quite different information. Further, the contribution analyses four differences that occurred only in boys and eight differences that occurred only in girls and comments on their specific qualities. In both cases the arbitrary variables were pupils' sex and nationality. Although the results of this research cannot be overestimated, some suggestions of speculations are offered, for instance whether internal worlds of our middle-school children are formed favourably in terms of values, why this happens or why this does not happen at all.

Statistically significant differences were registered in pupils' statements, concerning both the value-oriented manifestations of their families (see hereinafter: "At home, I am afraid to say what I am thinking about.", "At, home I am afraid of my parents having an argument.", "My parents spend a lot of free time with me.", "At home it holds: "He that will eat the kernel must crack the nut.", "At home we hold family rituals in esteem.", "When at home, I am afraid of punishment for my failure.", "My parents buy branded things for me.") and the pupils' own value standpoints (see further graphs -"I spend my leisure time in an active/passive way.", "I help other people of my own 


\section{Acta Technologica Dubnicae \\ volume 5, 2015, issue 2}

accord.", "I am persistent, I do not give up.", "I solve my problems with my peers."). In all above-mentioned cases it always matters whether boys and girls attend primary school in Bohemia or in Slovakia and whether they grow up in the Czech or Slovak environments.

\section{Results and discussion}

\subsection{Differences in value-orientation among schoolboys}

The differences among boys from both Czech and Slovak families concerning their perception of fear from the point of view of whether they are able to express what they are thinking about at home proved to be statistically significant. While among Czech boys, the rejection of the feeling of fear prevailed (the aggregate of Definitely NOT and Rather NOT $66.7 \%$ ), Slovak boys expressed their tendency to this fear at the level of $47.4 \%$ (22\% of which were categorical) - see fig. 3 .

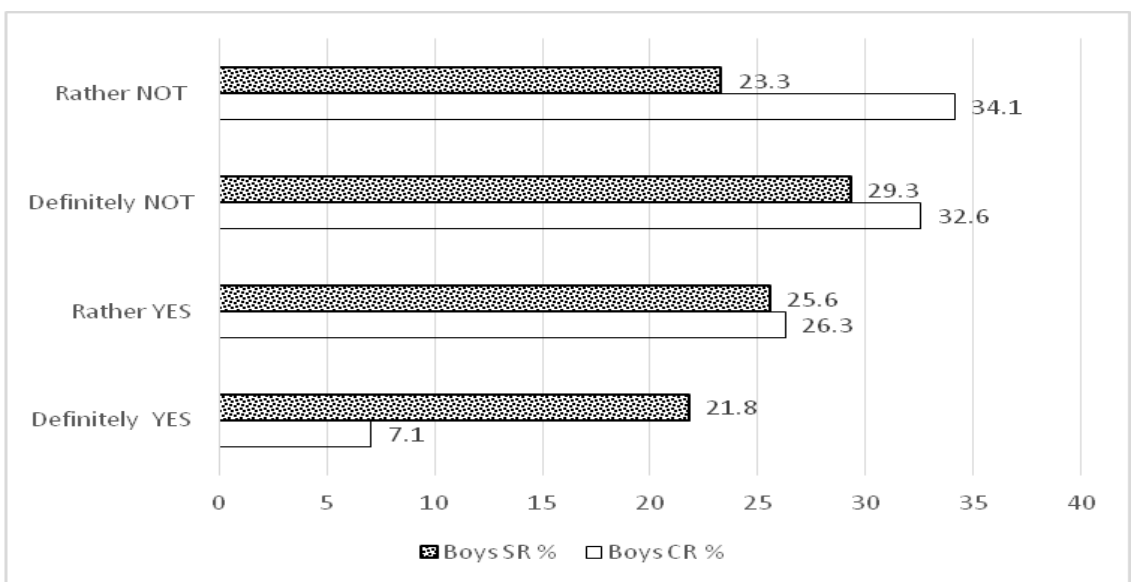

Pearson Chi-square: $19.3545, \mathrm{p}=0.000231$

Figure 3. At home, I am afraid to say what I am thinking about.

Thus Slovak boys feel less secure at home while expressing their views and opinions. The reasons for the above-mentioned situation can be seen not only in the type of the family (complete, incomplete, integrated, compensatory, or a family with a common-law husband or wife (Dunovský, 1986, p. 25)) and situations associated with the performance of its functions (a family with stabilized functions, a family with problems, a dysfunctional or non-functional family), (Helus, 2007, p. 149.), but also in historical relations and the 


\section{Acta Technologica Dubnicae \\ volume 5, 2015, issue 2}

educational levels of the family - authoritative vs. benevolent (Gillernová, 2004, p. 2). The functioning of the family and the scope of the background created for children, appear to be decisive for the harmonious development of a child. The possibility to be able to discuss their viewpoints, opinions, attitudes and actions, including their own imperfections is a key moment for pupils from the point of view of their formation and for creating certainty/security, i.e. the feeling that pupils have their own "definite viewpoint in the cosmos". It is one of the preconditions for the individual development that pupils can achieve with the help of their families. In the absence of that, the situation results in their imitating the behavioural patterns of their parents when the school children become adults.

The problem surrounding the fear of tying school children down within the family environment appears in the pupils' statements once more, this time in the form of fear on the part of parents involved in an argument - see fig. 4.

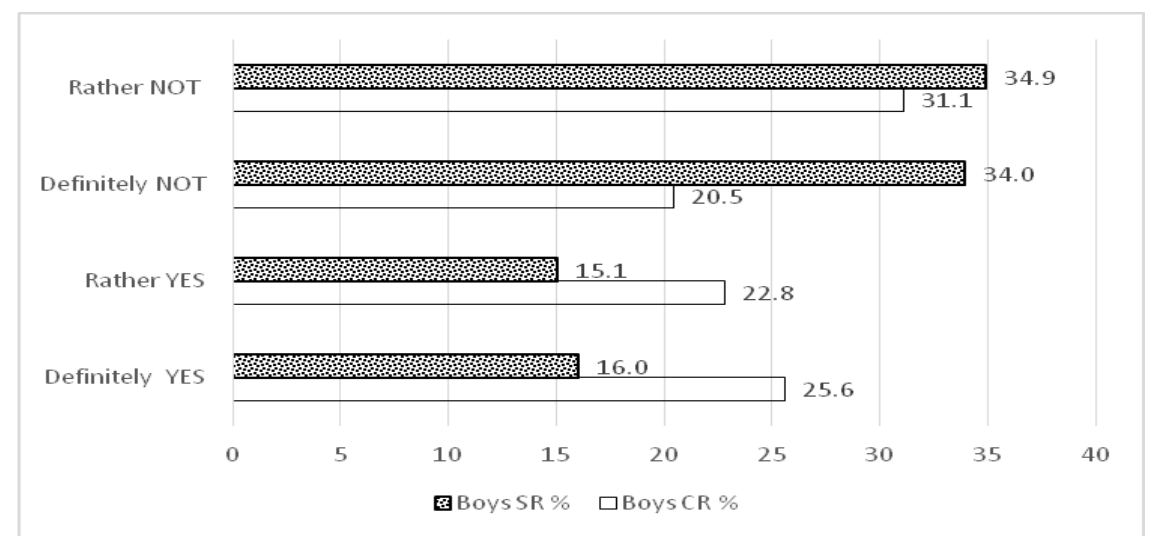

Pearson Chi-square: $11.0795, \mathrm{p}=0.011306$

Figure 4. At home, I am afraid of my parents having an argument.

As is evident from the graph, this time the Czech students of middle-school age, pupils confirmed that they were under an enormous pressure resulting from the fear of their parents' rows (the aggregate of Definitely YES and Rather YES $48.4 \%$ ) than their Slovak peers (the results of Definitely YES and Rather YES $31.1 \%$ ). From the above-mentioned, it is possible to deduce less matrimonial harmony in the families of the investigated sample of Czech schoolmates, which can have several different causes and in the research unspecified causes. Thus, it is impossible to exclude either internal causes (features of character, value preferences and expectations, health problems, etc.), or some other external 


\section{Acta Technologica Dubnicae \\ volume 5, 2015, issue 2}

causes (such as unemployment, economic deprivation, situations of crises, e.g. consequence of the life style, etc.). Under all circumstances, irrespective of the reasons, the atmosphere of fear does not contribute to the healthy development of pupils' positive and active approach to life which should be the main concern of the school population of that age.

Further two statistically significant differences discovered by research in the middle-school age population of boys, were concerned with their statements about their self-perception and their preferences. $90.8 \%$ of the Slovak boys, compared to $80.4 \%$ of their Czech peers, characterised themselves as being steadfast and persistent. The rejection of this feature of character prevailed, on the contrary, on the Czech side - see fig. 5.

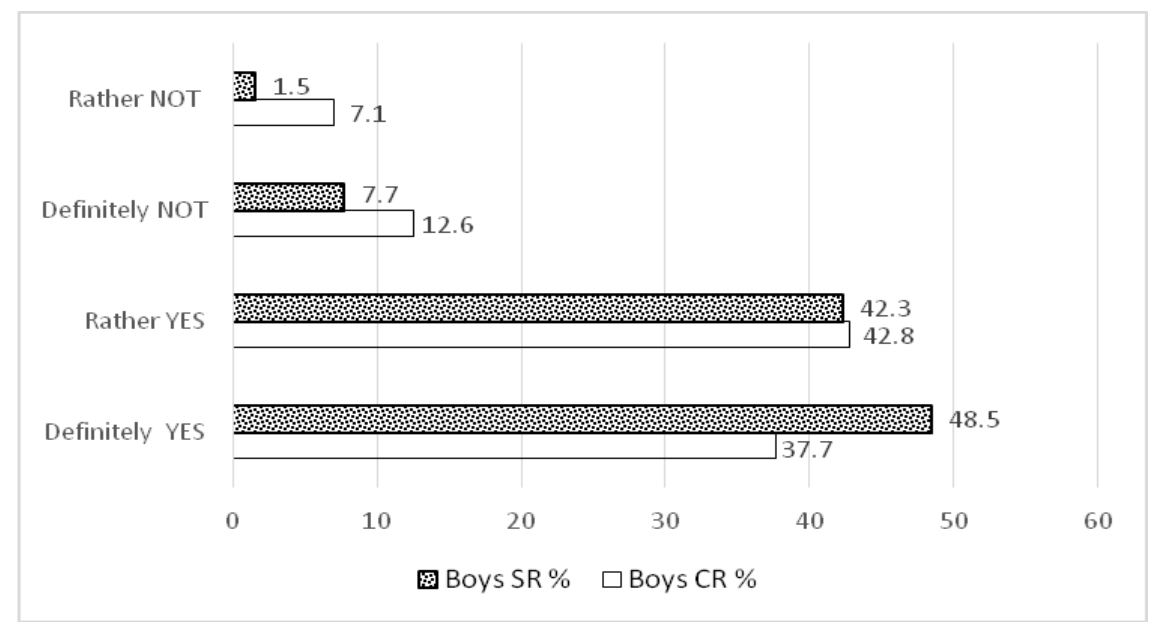

Pearson Chi-square: $9.35510, \mathrm{p}=0.024928$

Figure 5. I am persistent, I do not give up.

No matter how purely subjective the assessment of the pupils' degree of perseverance can be, which can be either overestimated or underestimated by individual pupils, it is always concerned with the characteristics necessary for overcoming obstacles and removing their own imperfections (both at school and in their lives). Thus, on the Czech side, its absence is expressed more frequently (the total of Definitely NOT, Rather NOT appears in $19.7 \%$ of cases), there is also a smaller predisposition towards the effort and willingness to achieve certain goals and a larger prerequisite for giving up or becoming resigned to doing certain things. 


\section{Acta Technologica Dubnicae \\ volume 5, 2015, issue 2}

The last statistically significant deviation - registered in the sample of selected Czech and Slovak boys - appeared in their preferences concerning leisure time. From the point of view of the fundamental difference - whether pupils spend their leisure in an active or passive manner - a statistically significant deviation has been confirmed with the spending free time passively - see fig. 6 .

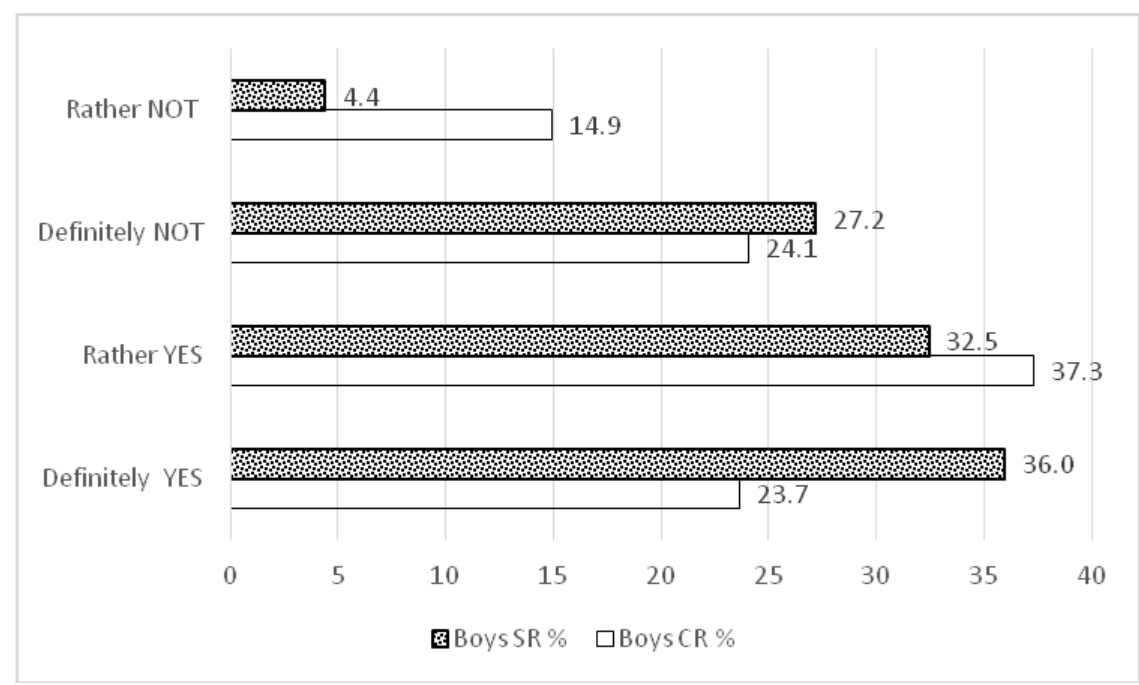

Pearson Chi-square: $12.5302, \mathrm{p}=0.005773$

Figure 6. I spend my leisure in a passive manner, in front of TV or PC...

A distinct supremacy of categorical consent among Slovak pupils with spending free time passively $(36 \%)$ is evident from the reading of graph 5 and a dominance of weak disagreement appears to characterize spending leisure time among Czech pupils (14.9\%). Otherwise the statements of Czech and Slovak boys are rather similar (the aggregate of Definitely YES and Rather YES in Slovak boys $-68.4 \%$ have a slight supremacy over the statements from Czech boys $-61.0 \%)$.

\subsection{Differences in value-oriented propositions of the school girl population}

Girls in our research showed themselves to be more sensitive and perceptive than boys (Vomáčka, 1994, p. 64). We were able to register statistically significant differences only in eight cases arising from the statements of Czech and Slovak schoolgirls. Just as in the case of boys, the statements can be divided into those characterizing the value-orientation and their families' attitudes on the one hand and those concerning their own preferences on the other hand. The first 
of these groups is represented by five of the statistical and conclusive connections mentioned below - see fig. 7 - 11 .

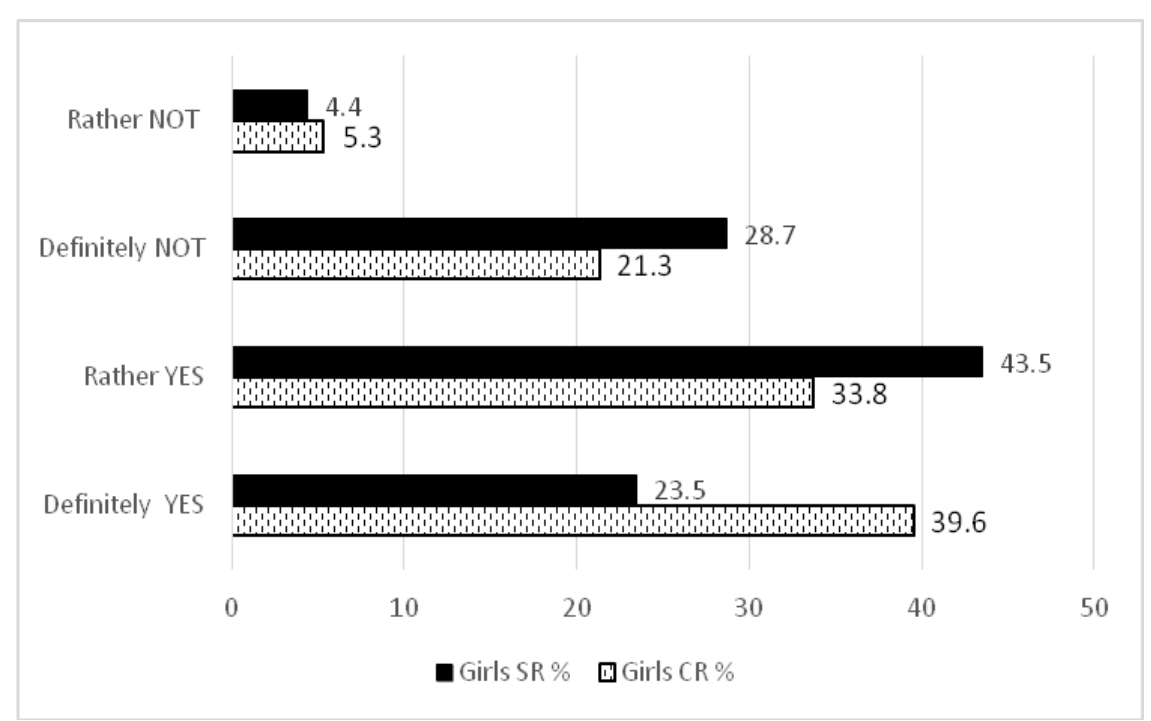

Pearson Chi-square: $9.57738, \mathrm{p}=0.022526$

Figure 7. My parents spend a lot of free time with me in an active way.

The parents' value orientation can be looked at by means of the pupils' comments on their active leisure time spent along with their parents. While Czech girls were ahead of their Slovak counterparts with their clear-cut confirmation of free time spent together actively (39.6\%) and with less denial with respect to this aspect (Rather NO $5.3 \%$ ), the Slovak girls were ahead of their Czech peers in their outright rejection of this statement $(28.7 \%)$ and with the weak level of consent (Rather YES $43.5 \%$ ). The emerged information suggests that Czech families within the monitored sample devote their active leisure time to their children in a more goal-directed way and transparently (for instance, along with their children they ride a bike, play party games, take them to their trainings and competitions in various sports and games). In general, active spending free time of parents and their children together can be regarded as a positive phenomenon. The parents' behaviour functions here as natural motivator for pupils' activities since they fill in their free time in a meaningful way. Thus they can strengthen - while learning about themselves- the cohesiveness of the family as a whole. 


\section{Acta Technologica Dubnicae \\ volume 5, 2015, issue 2}

The formation of values within families has a significant and formative influence on the school population. In the case of the carried out research survey, we discovered on the part of Czech and Slovak girls a statistically significant difference in terms of the application of the family principle "He that will eat the kernel must crack the nut."- see fig. 8 .

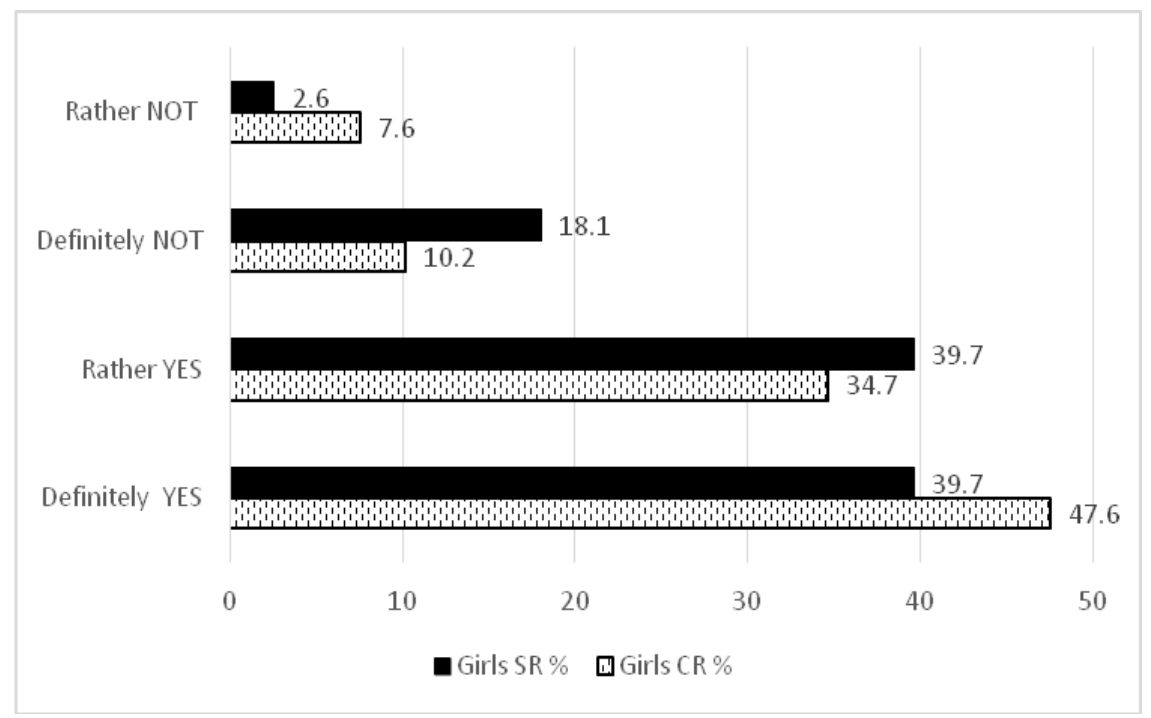

Pearson Chi-square: $8.49563, \mathrm{p}=0.036811$

Figure 8. It is true at home that: "He that will eat the kernel must crack the nut.".

In the distribution of predominating/prevailing percentage occurrence, we observed a repetition of the situation from the previous graph. The Czech girls uniquely confirmed (Definitely YES) that they must deserve certain things, i.e. to work their credits in $47.6 \%$ of cases, while with their Slovak counterparts a unique consent was given only in $39.7 \%$ of cases. On the contrary, the explicit disagreement (Definitely NOT) was given in a higher percentage of cases (18.1 $\%$ ) by Slovak girls, while among Czech girls the unique/explicit disagreement appeared in $10.2 \%$ of cases. Based on the above stated facts, the situation proved to be more stringent among girls in Czech conditions than in Slovakia.

Besides the development of pupils' awareness concerning duty and responsibility, family communities can also develop the awareness of internal unity and assist with the development of emotional relations, including intergenerational links. Within this research survey, the pupils were asked whether 
they respect family rituals (for instance joint Sunday dinners, joint celebrations of birthdays, spending holidays together). In the case of girls we registered a statistically significant difference between Slovak and Czech girls - see fig. 9.

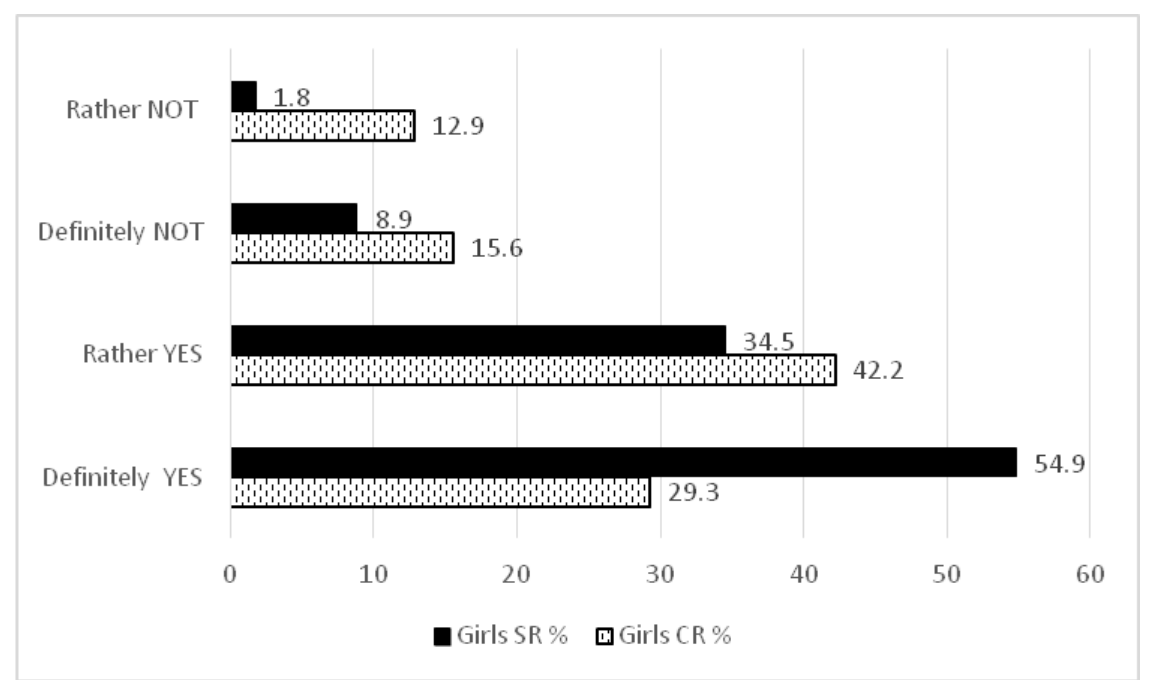

Pearson Chi-square: 26.587, $\mathrm{p}=0.000007$

Figure 9. At home we hold family rituals in esteem.

The dominance of the standpoint of negation on the part of Czech girls (the aggregate of Definitely NOT and Rather NOT $-28.5 \%$ ) over the Slovak girls $(10.7 \%)$ corresponds with the dominance of the positive point of view on the part of Slovak girls (the aggregate of Definitely YES and Rather YES - 89.4\%) over the Czech girls $(71.5 \%)$. Thus, although Czech girls demonstrate in relation to being more responsible with respect to the fulfilment of their duties (see graph 8), they are far less influenced by their families emotionally and are more bound to terms of relations, to this primary social community. It is possible to deduce that they are bound more frequently towards the performance of their obligations (e.g. carry out your duties and then you can go to the cinema with your friend) than towards relations and emotions (e.g. you can't go to the cinema when we are going to congratulate your granny on her birthday). Under Slovak conditions it seems to be vice versa.

Families burdened with problems may, on the contrary, render the emotional development of their children even more difficult. Helus (2006, p. 153 et seq.) refers to nine characteristic symptoms distinctive of the family between perfectionist and authoritarian, a statistical significance manifested itself as a 


\section{Acta Technologica Dubnicae \\ volume 5, 2015, issue 2}

deviation between Czech and Slovak girls within our survey. Specifically, it was in the case of an answer to the question as to whether pupils at home were afraid of any punishment for failure on their part. Success was not specified in the question, but it was evident that it dealt with recognition for the pupils' fulfilment of a specific school performance or a result acquired in a club or in an interest group, in sporting activities, etc. The girls who expressed their consent with the proposition thus indicated that their family required and expected that their children would always be successful under all circumstances. In addition, this permanently perceived family burden is associated here with a negative result - i.e. punishment - for their failure or for not being able to achieve their results or targets. The results of this research survey are manifested in fig. 10.

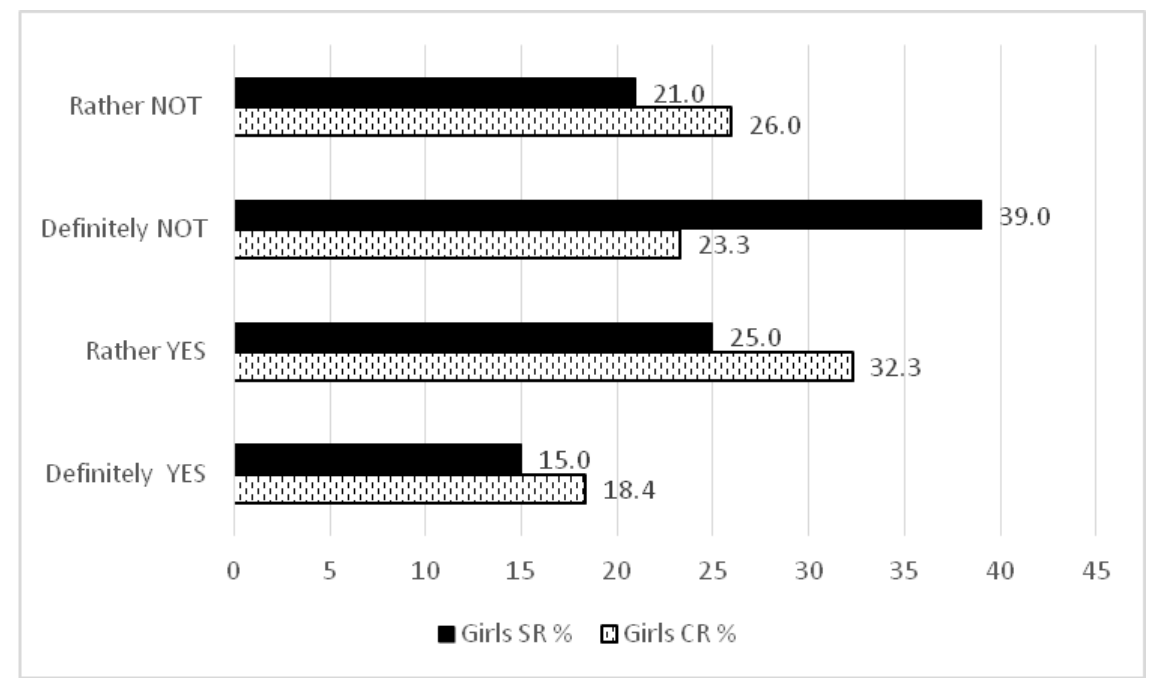

Pearson Chi-square: $8.41167, \mathrm{p}=0.038233$

Figure 10. At home, I am afraid of punishment for failure on my part.

More unambiguously than in all other above-mentioned cases, it was proved that Czech girls come under pressure due to their fears from the consequences of performing at a certain level (the aggregate of Definitely YES and Rather YES $50.7 \%$ ) more often than their Slovak peers (40\%). On the contrary, Slovak girls expressed categorical disagreement with this statement (Definitely NOT - $39 \%$ ) at a higher level of more than 15 percentage points in comparison with the Czech girls. The hidden danger in this finding can be gleaned by the fact that any insufficiency in the form of failure is perceived by the family, and figuratively also by its children, as a catastrophe. This is perceived by the family as anguish and disappointment accompanied by disharmony in the parent-child 


\section{Acta Technologica Dubnicae \\ volume 5, 2015, issue 2}

relationship, which can also be understood as the child's loss of security, understanding and love.

The last of the propositions that characterizes the value orientation of the family in which the girls are living is associated with one of the signs of an ambitious family. It testifies to the inclination to the polarities of the Fromm conception of "to be" or "to have" (1994, p. 32), expressed by the following statement: "My parents often buy branded things for me" (see fig. 11). The hidden danger in the families of this type is represented by the value orientation towards a high material standard which replaces emotional ties, love and time devoted to children. According to the carried out research, it has been shown that in this respect, Czech girls are more exposed to danger.

The distribution structure of frequencies in fig. 11 is, again, similar to that in the previous graph. It is evident that Czech girls are given more luxury in the form of expensive branded things (the aggregate of Definitely YES and Rather YES covers $49.8 \%$ ) more often than their Slovak peers (35.8\%). On the contrary, the Slovak girls categorically rejected, in 50\% off cases, that their parent would let them have such privileges.

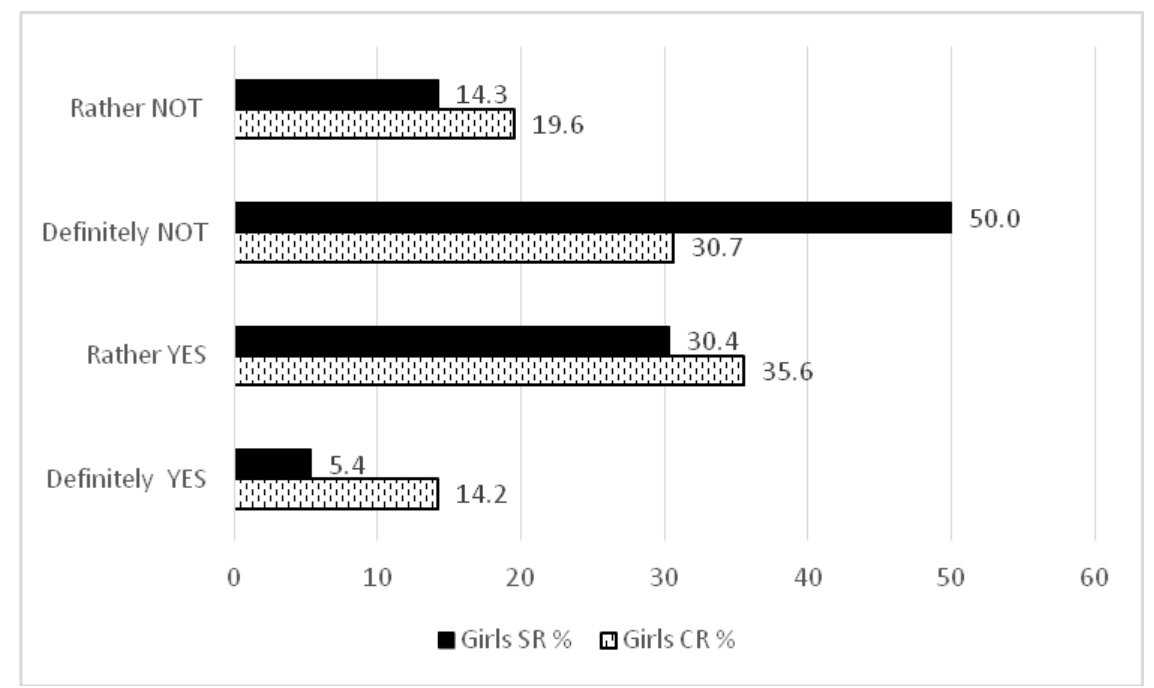

Pearson Chi-square: $14.5108, \mathrm{p}=0.002287$

Figure 11. My parents often buy branded goods for me.

Differences between the Czech and Slovak nations among middle-school age girls were also found in the case of spending their leisure time. The influence of 


\section{Acta Technologica Dubnicae \\ volume 5, 2015, issue 2}

their parents can be seen even in this sphere, in particular from the point of view of spending their leisure in an active or passive way. In spite of the fact that the research carried out proved a more active co-participation on the part of parents of the Czech girls (see fig. 7), the majority of the Slovak girls pointed out that they spent their leisure time actively (see fig. 12).

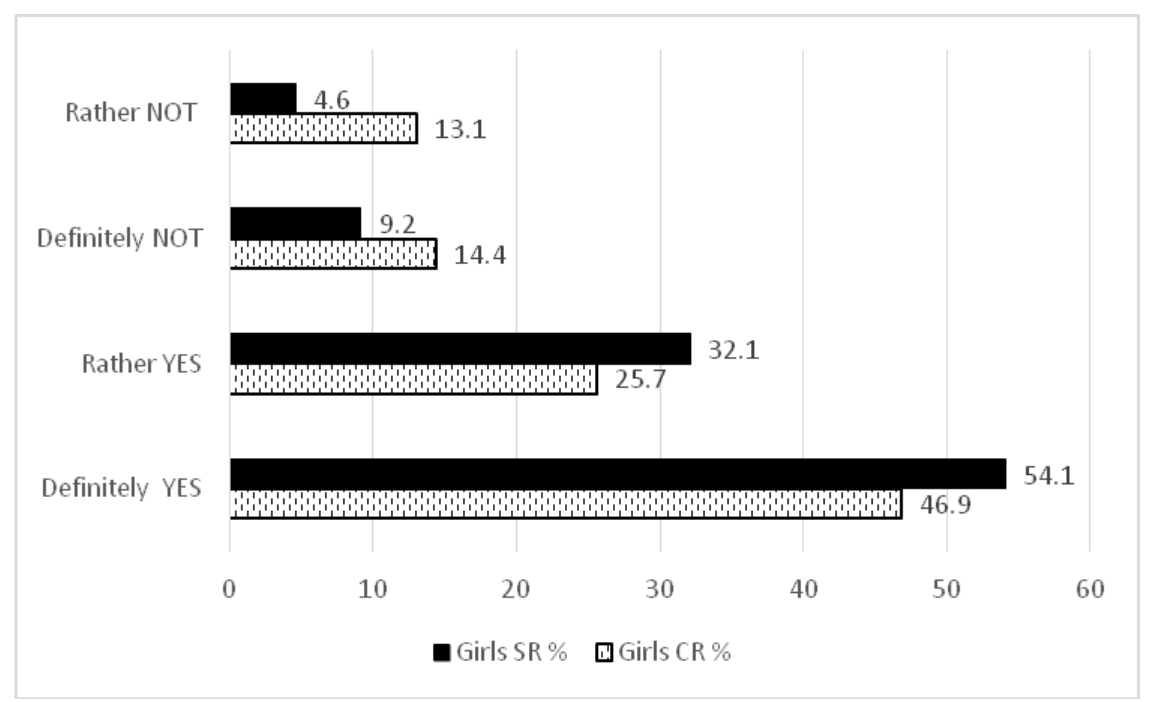

Pearson Chi-square: $8.57106, \mathrm{p}=0.035578$

Figure 12. I spend my leisure time in an active way (hobby groups).

With this question the polarity of answers was equally distributed: the Slovak girls exceeded the positive standpoints of their Czech peers with superiority of 13.7 points and the Czech girls exceeded the negative standpoints of their Slovak peers with the higher level of 13.7 percentage points. Apart from the proved statistical relations, it is also possible to deduce that Czech girls spend much more free time in a passive way (e.g. in front of TV sets, with their computers) than in an active manner (for instance by going in for sport or tourism, by singing or playing a musical instrument).

The perception of self has been verified by both Czech and Slovak girls in a statistically conclusive manner and differently in the case of the proposition "I help other people of my own accord."- see fig. 13. 


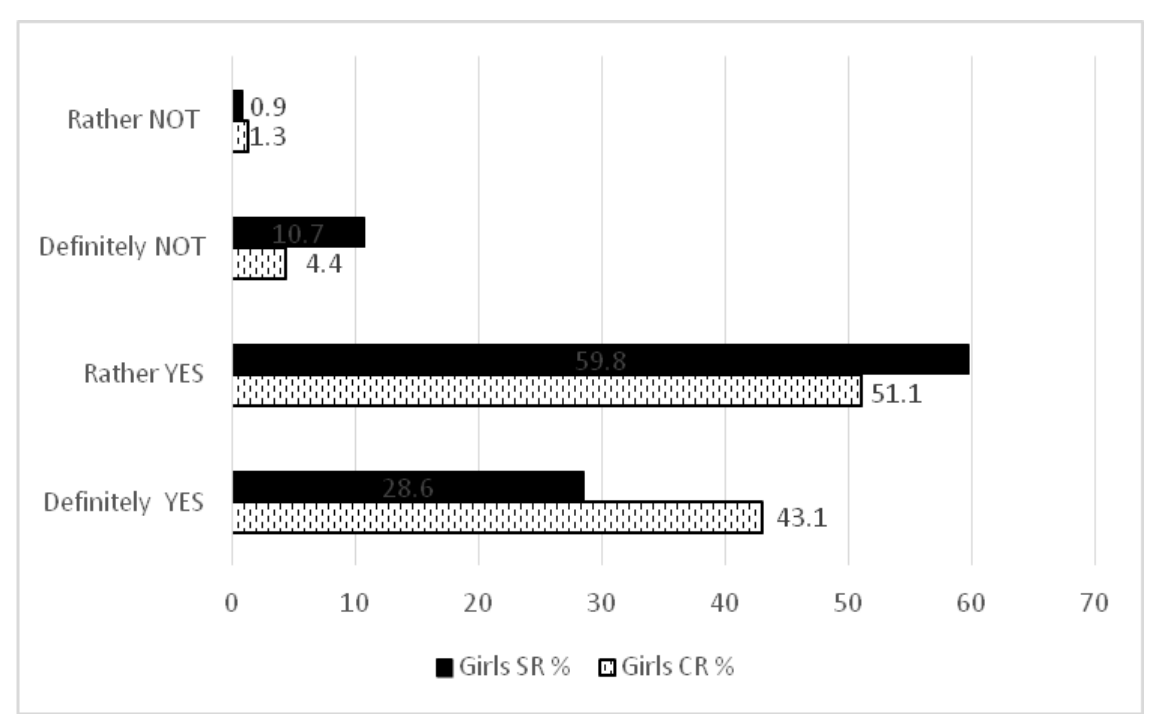

Pearson Chi-square: 9.80534, $\mathrm{p}=0.020299$

Figure 13. I help other people of my own accord.

While Czech girls dominated in the categorical agreement/consent (Definitely YES $43.1 \%$ ) over their Slovak peers (Definitely YES 28.6\%), the Slovak girls on the contrary dominated in the categorical disagreement (Definitely NOT 10.7 $\%)$ over their Czech peers (Definitely NOT $4.4 \%$ ). Although the overwhelming majority of the girls in both these groups evaluated themselves as altruistically oriented (the aggregate of Definitely YES and Rather YES in Czech girls covered $94.2 \%$ and in the Slovak girls $88.4 \%$ ), the girls on the Slovak side express, in more than $10 \%$ of cases, unwillingness to do that. The reason can be looked for either in personal experience (I haven't been helped by anybody either), or in the liberally set political environment (each of us has the same possibilities and therefore let everyone help themselves).

The problem of pupils' trust and belief in somebody in this research survey was verified by the questions about a person the pupils most frequently solve their problems with (e.g. about the pupils' mothers, fathers, brothers or sisters, fellow students). In the case of these Czech and Slovak girls a statistically significant deviation was discovered in their evaluation of fellow students - as trustworthy persons - who can help with the solution of their personal problems (see fig. 14). The Czech girls in the sample monitored by our team exceeded with their belief in their fellow students their Slovak peers (the aggregate of Definitely YES and Rather YES $35.5 \%$ in Czech girls, $25.0 \%$ in Slovak girls). Thus the Slovak 
girls did not manifest such a strong belief in their fellow students and while solving their problems they probably turn their attention to other persons.

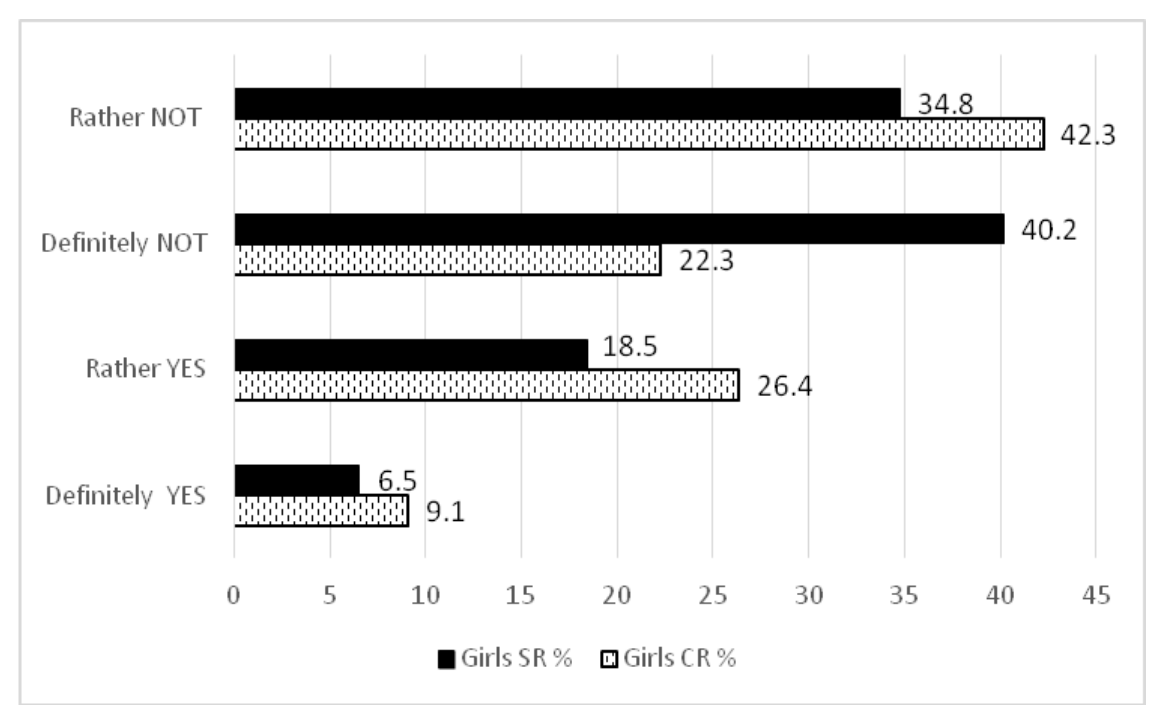

Pearson Chi-square: 10.6787, $\mathrm{p}=0.013599$

Figure 14. Most frequently I solve my problems with my schoolmates.

\section{Conclusion}

This research paper has pointed out, in a selective manner, that there are differences in the statements of Czech and Slovak middle-school aged pupils connected with their value-oriented view of the world. The research team has intentionally selected the statistically evidential connections on account of the pupils' differing nationality, which were found in both boys and girls. Both the sexes in these cases gave evidence of rather different "Czech and Slovak" preferences among themselves or in their families. Although this was not a representative sample of respondents, it provided evidence with respect to the consideration of its percentage of occurrence (frequency), the team with some interesting and statistically significant findings. It is necessary to grasp, interpret and evaluate them in the context of the students' age. The boundary between 9/10 to 12/13 years is considered to be a turning point from the point of view of transformation of heteronymous morals to autonomous morals. It has been demonstrated that a pupil matures in terms of moral values no sooner than between the sixth and the eighth form (Vacek, 2008, p. 72). However, the differences discovered among the 9- to 12- year old Czech and Slovak pupils cannot be overestimated. Notwithstanding they provoke a number of questions 


\section{Acta Technologica Dubnicae \\ volume 5, 2015, issue 2}

in the light of signals concerning a shift of values in the independently functioning Czech and Slovak states. From the point of view of another perspective, it is not irrelevant how the value system and the value orientation has been formed during their school age, how it will be projected into their actions and experiences in adulthood and how important this source of motivation or, on the contrary, demotivation, can be for their future active participation in society.

\section{Acknowledgements}

This contribution has been created within research supported by an UJEP SGA Grant 4320115000501 .

\section{References}

Balcar, K. (1991). Úvod do studia psychologie osobnosti. Chrudim: Mach. Bělohradský, V. (2011). Vzít reformismus vážně. Právo, 2011, March 19.

Bedrnová, E., Nový, I. et al. (2009). Psychologie a sociologie řizení (3rd ed.). Praha: Management Press.

Blížkovský, B. (1997). Systémová pedagogika. Celistvé a otevřené pojetí vzdělávání a výchovy. Brno: Amosium Servis.

Cakirpaloglu, P. (2009). Psychologie hodnot. Olomouc: Univerzita Palackého.

Čačka, O. (1994). Psychologie ditěte. Tišnov: Sursum.

Čáp, J., \& Mareš, J. (2007). Psychologie pro učitele (2nd ed.). Praha: Portál.

Dunovský, J. (1986). Dítě a poruchy rodiny. Praha: Avicenum zdravotnické nakladatelství.

Ferjenčík, J. (2000). Úvod do metodologie psychologického výzkumu: jak zkoumat lidskou duši ( $1^{\text {st }}$ ed.). Praha: Portál.

Fromm, E. (1994). Mit nebo být? Praha: Naše vojsko.

Gillernová, I. (2004). Způsob výchovy v současné české rodině z pohledu dospívajících chlapců a dívek. D. Heller, J. Procházková, \& I. Sobotková (Eds.). Psychologické dny 2004, Olomouc: Univerzita Palackého v Olomouci. Retrieved from http://cmps.ecn.cz/pd/2004/texty/pdf/gillernova.pdf

Göbelová, T. (2004). Uvedeni do výchovné problematiky na prvním stupni ZŠ. Ostrava: Repronis.

Helus, Z. (2009). Dítě v osobnostním pojetí: obrat $k$ dítěti jako výzva a úkol pro učitele i rodiče (2nd ed.). Praha: Portál.

Helus, Z. (2007). Sociálni psychologie pro pedagogy. Praha: Grada.

Horák, J. (1996). Kapitoly z teorie výchovy. Problematika hodnot a hodnotové orientace (1). Liberec: Technická univerzita.

Kohoutek, R. (2009). Etika a prosociálni jednání. Retrieved from http://rudolfkohoutek.blog.cz/0912/etika-a-socialni-jednani 
Langmeier, J., \& Krejčířová, D. (2006). Vývojová psychologie (2nd ed.). Praha: Grada.

Matějček, Z. (2008). Co děti nejvíc potřebují (5th ed.). Praha: Portál.

Matějček, Z., \& Dytrych, Z. (2002). Krizové situace v rodině očima ditěte (1st ed.). Praha: Grada.

Měkota, K., \& Blahuš, P. (1988). Antropomotorika II. Praha: SPN.

Prudký, L. et al. (2009). Inventura hodnot, výsledky sociologických výzkumů hodnot ve společnosti České republiky. Praha: Academia.

Svoboda, Z., Smolík, A. et al. (2010). Pedagogická, sociální a zdravotnická práce s osobami ohroženými sociálním vyloučením. Ústí n. L.: UJEP.

Vacek, P. (2008). Rozvoj morálního védomí žákư, metodické náméty $k$ realizaci prưrezových témat. Praha: Portál.

Vágnerová, M. (2005). Vývojová psychologie I. Dětství a dospivání. Praha: Karolinum.

Vomáčka, J. (1994). Děvčata a chlapci. K pedagogické problematice jejich intersexuálních zvláštností. Ústí n. L.: Univerzita J. E. Purkyně.

Vomáčková, H., \& Cihlář, D. (2013). Rodinné propylaje v pedagogickém nástinu. Ústí n. L.: Univerzita J. E. Purkyně. 